\title{
The Effect of Google Classroom in Blended Learning on University Students' English Ability
}

\author{
Liya Astarilla Dede Warman ${ }^{1}$ \\ ${ }^{1}$ STMIK-AMIK Riau, Pekanbaru, Indonesia \\ email: liya.astarilla@gmail.com
}

\begin{abstract}
This research aimed to investigate Google Classroom's effect on blended learning on university students' English ability. This research utilized a quasi-experimental design which included experimental and control group design. The study participants comprised 68 students in the first semester at STMIK-AMIK Riau in Pekanbaru-Riau, Indonesia. This research instrument was an achievement test in multiple-choice questions administered to the participants in pre-test and post-test. The quantitative data were collected by using pretest and post-test to gauge the students' English ability before and after conducting the treatments in both groups. The finding revealed that statistically, there was a significant difference in the mean score between the experimental and control group in the post-test. The experimental group that learned English through Google Classroom in blended learning achieved a significantly higher score than control group that learned English through the conventional method. It was proved that the t-test was higher than the t-table value $(5.270>2.042)$ at the level of significance 0.05 and $p=0.000$. This study concluded that blended learning through Google Classroom had contributed to the improvement of students' English ability.
\end{abstract}

Keywords: Google Classroom, English ability, blended learning.

\begin{abstract}
Abstrak
Penelitian ini bertujuan untuk menginvestigasi pengaruh Google Classroom dalam Blended Learning terhadap kemampuan Bahasa Inggris mahasiswa. Penelitian ini merupakan penelitian quasy-experimen dengan menggunakan desain kelompok eksperimen dan kelompok control. Partisipan dalam penelitian ini terdiri dari 68 orang mahasiswa di STMIK-AMIK Riau di Pekanbaru-Riau. Instrumen yang digunakan pada penelitian ini adalah achievement test dalam bentuk pilihan ganda, yang digunakan sebagai pre-test dan post-test. Data kuantitatif dikumpulkan melalui pre-test dan post-test untuk mengukur kemampuan Bahasa Inggris pada kedua kelompok sebelum dan sesudah mendapatkan treatmen. Temuan pada penelitian ini mengungkapkan bahwa ada perbedaan yang signifikan secara statistik pada nilai rata-rata post-test antara kelompok eksperimen dan nilai kelompok control. Kelompok eksperimen yang belajar Bahasa Inggris melalui Google Classroom dalam Blended Learning mencapai nilai yang lebih tinggi dibanding nilai kelompok control yang belajar Bahasa Inggris melalui metode konvensional. Terbukti dengan nilai $t$-test lebih tinggi daripada nilai t-table $(5.270>2.042)$ dengan tingkat signifikan 0.05 dan $\mathrm{p}=0.000$. Penelitian ini menyimpulkan bahwa Blended Learning melalui Google Classroom berkontribusi pada peningkatan kemampuan Bahasa Inggris mahasiswa.
\end{abstract}

Keywords: Google Classroom, English ability, blended learning. 


\section{INTRODUCTION}

Nowadays, with the proliferation of information and Communication Technology (ICT) in all aspect of people's life, there is no refuting that it also significantly changed the paradigm of education all over the world. The development of technology ushered in the new teaching and learning methods, media and sources. In Indonesia educators are trying to extend their teaching method by integrating technology into their classroom in order to improve the quality of teaching that result in students' motivation, participation and learning outcome. Technology has been proven to increase students' active participation and learning outcomes (Kuh et al, 2001). One of the objectives of Indonesian Qualification Framework Curriculum (KKNI) is to increase the quantity and quality of Indonesian resources in order to grant greater access to both national and international job market after students graduating from university. However, according to Law Number 20 of National Education System of Indonesia in the year 2003, it is asserted the importance of facilitating distance education namely online learning at all level of education (Depdiknas, 2003). Besides, concerning to the new regulations of Directorate General of Higher Education, Ministry of National Education and Culture (2020) states that the curriculum applied at a university level must be adjusted based on industrial revolution 4.0 needs. Therefore, e-learning or blended learning at a university must be applied because the use of technology and internet can support teaching and learning activities. Blended learning as kind of distance learning that combine face-to-face and online teaching incorporates technologies along with common classroom teaching (Kintu et al, 2017). Furthermore, Hinneburg et al (2020) points out that blended learning is an opportunity to integrate technology and innovation provided by online learning with conventional learning method, interaction and participation. It means that blended learning is characterized by combining online and face-to-face learning method. In short, lecturers must integrate technology in conducting blended learning to enhance students' knowledge and skills.

In fact, English is an indispensable skill that must be have by university students in that it is not only used to enrich their knowledge the during study at a university, but also important for their future because English is a lingua franca which is used as a global means of communication all over the world. However, educators must find appropriate methods and ways to prepare students before entering workforce by improving their knowledge and English skills during the study at a university. Based on the researcher's experience and observation as a lecturer in teaching the first semester students, regardless the fact that they have learned English since in elementary school, they still have poor English, especially those who came from rural area or village. They have inadequate exposure to English because they only learned English once a week at school via textbook. Furthermore, due to the limitation of facilities like internet and computer at their area, they did not have any experiences in applying technology or online learning at school. They were also seldom exposed to English materials outside the classroom which resulted in the lack of vocabulary and low proficiency of the four English language skills. These problems influenced their motivation in learning English. The researcher need to solve this problem in order to increase the 
students' motivation in learning English and their achievement. Learning English only in the classroom is not enough to deal with this problem. Thus, in this study technology was integrated in blended learning to elevate the students' motivation in learning English outside the classroom.

After learning various applications of education or web-based learning management system and reviewing the pilot studies, the researcher decided to apply Google Classroom into students' learning activities. Google Classroom is designed by Google in 2014 for academic purposes to support blended learning. This application is easy to use, it does not take too much memory on smartphone and can help teacher and students keep on the lesson's track. Google Classroom is a newly recognized, innovative, and considered as one the best platforms for teaching and learning (Al-Maroof \& Al-Emran, 2018). It provides a set of powerful features that make it a great tool for online learning. Janzen (2014) and Syakur et. al (2020) point out that there are several benefits of using Google Classroom. First, it is easy to use and designed to simplify the instructional interface for submitting and tracking assignment, and also for communication with students through announcement, email and push notification. Second, Google Classroom is developed to save time because it integrates and automates the use of Google docs, slides, spreadsheet, grading, formative assessment, and feedback. Third, Google Classroom is flexible. This app is easily accessible and useable to teachers and students in both face-to-face learning environment and online learning environment. Fourth, Google Classroom is free. Fifth, Google Classroom improves cooperation and communication. Lecturer and students can do online discussion, provide feedback and give score. Sixth, Google Classroom have centralized data storage. Everything is in one central location or students can see their assignment in a specific folder, lecturer can upload and save learning materials in the cloud. So, they do not need to worry about losing documents because all files stored in this application. The last, Google Classroom is mobile-friendly. It means it is easy to use on any mobile devices. It means that students can access the learning materials through their smartphone without any boundaries and spaces. In addition, there are four pages available on Google Classroom that are helpful to support online learning, namely (1) Stream. In this stream is a place where teachers share announcements and posts, (2) Classwork. It is the main page to organize assignments into units or folders. In this page, teacher can create questions, quiz, assignments, post materials for students, (3) People. In this page, teachers can notice list of teachers and students who enrolled in her class, and (4) Grades. In this page, the teachers can see all grades of her students. In short, the features of Google Classroom combined with the students' collaboration and independence play vital roles in the improvement of their English. It provides and gives the students chances to study on their own pace and time, so there is also a chance of improvement. By considering the problems of students in learning English language, the needs to have blended learning, and the roles of Google Classroom to support online learning, the researcher was encouraged to use Google Classroom to her students in blended learning environment. The purpose of this study is to investigate the effect of Google Classroom in blended learning on university students' English ability. 


\section{LITERATURE REVIEW}

\section{The Use of Google Classroom in English Language Learning}

According to Fonseca and Peralta (2019) Google classroom enables the teachers and students to share materials, assignments, quiz and even online discussion. No more paper needed for assignment or quiz. Teacher can post announcement and assign task for the students. Students can submit the assignment in the folder provided by the teacher in the platform. Iftakhar (2016) points out that Google Classroom helps teachers save time, keep classes organized and improve communication with the students. It is free and available to anyone with Google Apps for education. It allows teachers to spend more time with their students and less time on the paperwork. Moreover, Nagelle (2017) states that by using Google Classroom teachers can create active lessons which are student-centered, collaborative, and memorable since it provides easy-to-use learning features for students. Furthermore, Negara (2018) states that Google Classroom is an online application promoted by Google for school is an application intended to facilitate teachers or lecturers in compiling, creating, and assessing students' assignment by using automatic document storage and in a paperless way. In conclusion, Google Classroom is really useful for both teachers and students because it has several features that can create and manage assignment actively, communicate between teacher and students personally or give feedback. It is paperless and can be accessed anytime and anywhere by using smartphone or laptop as long there is signal or internet connection.

Some studies have shown a number of the effectiveness of using Google Classroom to improve students' English skills. Albashtawi and Khaleel (2020) investigated the effectiveness of Google Classroom among EFL students in Jordan. This study showed that Google Classroom can greatly improve the college students' performance of English as a Foreign Language especially on their reading and writing skills. Haggag (2019) in his study discussed the using Google Classroom in enhancing communicative grammar use on post-graduate student found that the development of grammar use and positive attitude on the students' performances after using Google Classroom in learning activities. Then, Dewle (2019) conducted a study to investigate the use of Google Classroom to improve listening skills in an English for academic purposes for students of the second semester at a university in India. The finding showed that Google Classroom platform was engaging and useful in improving students' listening skill. In another study, Fonseca and Peralta (2019) discussed the impact of using Google Classroom to teach writing skill in an EFL composition course at a national university in Costa Rica. This study revealed that the use of this platform gave benefits and helped students in developing their writing skill. They also found that Google Classroom was more satisfactory than other platforms. Next study was done by Wahyu et al (2018), this study analyzed the effect of blended learning using Google Classroom on writing ability of EFL students across autonomy levels of third semester students of English Department of Universitas Negeri Malang, Indonesia. The result from this research showed that the writing ability of the EFL students taught by using blended learning using Google Classroom was better than students taught by using conventional methods. They also pointed out that the features on Google Classroom could engage students in blended learning. In other words, Google 
Classroom is highly recommended to be applied to the students who learn English outside classroom due to its convenience features.

\section{METHOD}

\subsection{Research Design}

The research design was a quasyexperimental design. In this design, two groups were pretested, administered treatments, and postested (Gay et al, 2009). This research used pre-test and post-test in the experimental and control groups to investigate the students' English ability before and after treatments.

\subsection{Participants}

The participants of this study were 68 students of first year at the first semester majoring in Computer Science or Informatics of the 2019/2020 academic year at STMIK-AMIK Riau in Pekanbaru, Riau, Indonesia. They were selected by using purposive sampling method. 34 students were from class $\mathrm{A}$ as experimental group and the other 34 students were from class B as control group. There were 44 males and 24 females between the age ranges of eighteen to twenty. The researcher considered to use purposive sampling method in this research due to several factors. First, it is not possible to assign individual participants to group randomly. The researcher keep existing classrooms intact because the participants were her students that learning English in one semester. In other words, the researcher kept the entire students to the treatments because both of groups were taught by the researcher. Second, both of the groups' English abilities were equivalent. It is important to reduce some of threats and strengthen the study, the researcher should confirm that the groups were equivalent. It was also confirmed based on the students' score in the pre-test. Third, this method can minimize the reactive arrangement or Hawthorne effect that often occured when participants are randomly selected and assigned by the researcher. The using of classes intact in quasy-experimental, make all of the groups may not even be aware that they are involved in a study (Gay et al, 2009). All students were enrolled in Basic English subject, according to CEFR the content of lesson was at A1 level. All of participants reported they have smartphone or laptop.

\subsection{Data Collection and Analysis}

In this study, the researcher gave treatment to the students in 8 weeks. The experimental group conducted blended learning through Google Classroom outside the classroom as supplement to support face-to-face meetings in the classroom. Whereas, the control group was taught through the conventional method or without using Google Classroom. The control group only learned English through face-to-face meeting in the classroom by using textbook and printed materials. This group also did and submitted assignments via paper.

The researcher conducted this research based on following design to investigate the effect of Google Classroom on university students' English ability, as shown on figure 1 .

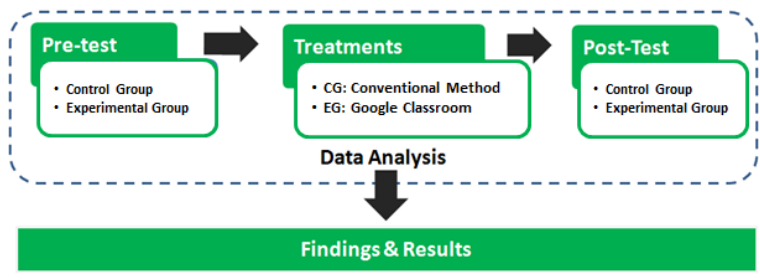

Figure 1: Research Design 
Due to the limitation of time, in this study the researcher only focused on investigating students' vocabulary, grammar, and reading comprehension ability. To measure participants' learned knowledge of the English language before and after the treatments, the researcher designed an achievement test as the instrument in this study. It was multiplechoice questions which consisted of 50 questions. The test items were devised by the researcher based on the syllabus and the course objectives. Further, the researcher determined using content validity in this study. It is in line with Underhill (1991) who points out that content validity refers to the concept if the test produces a reasonable sample of the contents of the textbooks and/or syllabus. Furthermore, Siddiek (2010) states that content validity as tests are supposed to focus on core syllabus constituents to find out how much the learner achieved. Therefore, the test in this study should reflect instructional objectives or subject matters of Basic English. The content validity of the test is determined by expert judgment and there is no formula or statistic and there is no way to express it quantitatively (Gay et al, 2009). The researcher discussed the test items with her colleagues. Several inapropriate questions were revised and replaced with the correct questions. Before conducting the pre-test, the researcher analyzed the reliability of the test instrument in order to ascertain the quality and internal validity of the test by conducting try out test to the other class that had the same characteristic with the participants. The result showed that the reliability calculated through Cronbach's Alpha formula was 0.80 . It means that the test was categorized into high reliability and acceptable.
At the first meeting, pre-test was administered to both of groups in order to know students' English ability before treatment. One day before starting the second meeting, all materials namely the lesson, videos and assignment were prepared by the researcher. The researcher created a class and uploaded the material on the Google Classroom platform that were used by experimental group. At the second meeting, the researcher introduced Google Classroom to the experimental group. They were asked to install the application of Google Classroom by using their smartphone or laptop and register into it by using their Gmail or Google account. The Google account is integrated with their Google Classroom and also with other Google's products. Then, students joined the class by using class code of the classroom that was informed by the researcher. Finally, students learned all features they could use on the Google Classroom, not only for reading and learning the materials given by the lecturer, but also for discussion, taking quiz or test, and submitting assignment. They also were guided and practiced how to submit their assignment and post their comments. Based on the researcher's observation, the students did not have any problems with the system or features used on the Google Classroom, since they were majoring in computer science or Informatics.

On the next meeting, the participants used Google Classroom outside the classroom. Both groups had the same treatment in the classroom. They learned English by using textbook, multimedia and conventional strategy in the classroom. Teaching method and strategy used by the researcher in teaching and learning activities in the classroom to both groups namely communicative language teaching. Besides, multimedia namely slides 
presentation, videos and audio were also used by the researcher in teaching English to both groups in the classroom. Both of groups learned new words in sentences, reading texts, and grammar. The difference was the participants in experimental group got more exposures of vocabulary, reading text, grammar lessons and did their assignment via Google Classroom outside classroom. Whereas, the participants in the control group only learned English through conventional method in the classroom. In addition, the control group only did and submitted their assignment directly to the lecturer without using Google Classroom.

Furthermore, the participants' activities and progress in experimental group automatically could be monitored and seen by the researcher on Google Classroom. She could see the information of the students' assignment submission status such as on time, late, or did not submit at all. The researcher gave another material and assignment via Google Classroom once a week outside classroom. When she have finished uploaded the assignment on the Google Classroom, the students would receive push notification on their Gmail, which topic that they should accomplish, and also the deadline or the schedule of the submission. Beside giving assignment, the researcher also provided additional materials every meeting on the Google Classroom such as authentic reading materials, videos, tasks that could improve the students' reading ability, grammar and vocabulary. In addition, she also invited the students to interact or discuss on the Google Classroom. Sometimes, a whole class online discussion were arranged on Google Classroom then they could discuss and ask questions related to the lesson. This way helped introvert students to share their opinion that usually passive in the classroom. In short, the students could use
Google Classroom to support their learning and interact with their friends and lecturer.

After conducting the treatment for 8 weeks, at the end of the semester the posttest for both groups was administered by the researcher in order to know the achievement between the experimental group that use Google Classroom in blended learning and control group that used conventional method. In analizing the data, the researcher used independent t-test and paired sample test available in Statistical Package for Social Science (SPSS) 21 version. Descriptive statistics were used to investigate the means and standard deviation of each variable. Then, the researcher compared both of groups' mean score before and after the treatment conducted by using an independent sample t-test and paired sample test to determine significant differences between the means of both groups.

\section{FINDING AND DISCUSSION}

The findings of this research are presented to ascertain the effect of Google Classroom on the students' English achievement. At the beginning of the research, pre-test was administered in order to investigate the equivalence of English achievement of the students in experimental and control groups before treatments. Therefore, the pre-test result from both of groups were analyzed in order to find if there were any significant differences between experimental group and control group before the experiment. Thus, independent sample t-test test was conducted, the findings as shown in the Table 1. 
Table 1. The Results of Independent Sample T-test in Pre-test

\begin{tabular}{||l|l|l|l|l|l|l|l||}
\hline $\begin{array}{l}\text { Descr } \\
\text { iption }\end{array}$ & $\mathbf{N}$ & Mean & $\begin{array}{l}\text { St } \\
\text { d. } \\
\text { Devia } \\
\text { tion }\end{array}$ & $\begin{array}{l}\text { Std. } \\
\text { Err } \\
\text { or } \\
\text { Mea } \\
\mathbf{n}\end{array}$ & $\mathbf{t}$ & df & $\begin{array}{l}\mathbf{P} \\
\text { Value }\end{array}$ \\
\hline $\begin{array}{l}\text { Expe } \\
\text { rime } \\
\text { ntal } \\
\text { Grou } \\
\mathbf{p}\end{array}$ & 34 & $\mathbf{6 1 , 1 4}$ & 9,06 & 1,55 & $-0,694$ & 33 & $\mathbf{0 , 4 9 3}$ \\
\hline $\begin{array}{l}\text { Cont } \\
\text { rol } \\
\text { Grou } \\
\mathbf{p}\end{array}$ & 34 & $\mathbf{6 2 , 3 2}$ & 7,41 & 1,27 & & & \\
\hline \hline
\end{tabular}

Table 1 shows that the mean score of the experimental group is 61.14 with a standard deviation of 9.06 and the mean score of the control group is 62.32 with a standard deviation of 7.41 . It reveals that there is no significant difference in the mean score of the pre-test at the 0.05 level $(\mathrm{t}=-0.694, \mathrm{P}>0.05)$. It is emphasized that participants between experimental and control group did not show any significant difference in pre-test. Hence, students in both of groups have the same level of ability before conducting the treatments.

Furthermore, to investigate whether there was any difference on students' English achievement of the both groups after conducting the treatments, the posttest were administered by the researcher. Next, the post-test' score were analyzed through independent sample T-test. The result was shown in the Table 2.
Table 2. The Results of Independent Sample T-test in Post-test

\begin{tabular}{||l|l|l|l|l|l|l|l||}
\hline Description & $\mathbf{N}$ & $\begin{array}{l}\text { Mea } \\
\mathbf{n}\end{array}$ & $\begin{array}{l}\text { Std. } \\
\text { Devi } \\
\text { ation }\end{array}$ & $\begin{array}{l}\text { Std. } \\
\text { Error } \\
\text { Mean }\end{array}$ & $\mathbf{t}$ & df & $\begin{array}{l}\text { P } \\
\text { Valu } \\
\text { e }\end{array}$ \\
\hline $\begin{array}{c}\text { Experiment } \\
\text { al Group }\end{array}$ & 34 & $\mathbf{7 9 , 7 6}$ & 7,56 & 1,30 & $\begin{array}{l}5,27 \\
0\end{array}$ & 33 & $\mathbf{0 , 0 0 0}$ \\
\hline $\begin{array}{c}\text { Control } \\
\text { Group }\end{array}$ & 34 & $\mathbf{7 1 , 1 4}$ & 6,71 & 1,15 & & \\
\hline
\end{tabular}

The result reveals that there is a statistically significant difference on both groups on the post-test result. It shows that the mean score of the experimental group is 79.76 with a standard deviation of 7.56 and the mean score of the control group is 71.14 with a standard deviation of 6.71. Furthermore, comparing t-test 5,270 which was higher than the t-table $2.042(\mathrm{df}=33$, $\mathrm{P}<0.05)$ we can conclude that t-test is higher than t-table. In means that there is a significant effect of using Google Classroom on students' English achievement.

To explore the improvement on students' English achievement within the same group on the results of pre-test and post-test of each group were analyzed by using paired sample t-test, as shown in the table 3 . 
Table 3. The Comparison of Mean Scores between Experimental and Control Groups

\begin{tabular}{||c|l|l|l|l|r||}
\hline \multirow{2}{*}{\begin{tabular}{c} 
Description \\
\hline
\end{tabular}} & \multirow{2}{|c|}{ N } & \multicolumn{2}{|c||}{ Pre Test } & \multicolumn{2}{c||}{ Post Test } \\
\cline { 3 - 6 } & & Mean & StDev. & Mean & StDev. \\
\hline $\begin{array}{c}\text { Experimental } \\
\text { Group }\end{array}$ & 34 & $\mathbf{6 1 , 1 4}$ & 9,06 & $\mathbf{7 9 , 7 6}$ & 7,56 \\
\hline $\begin{array}{c}\text { Control } \\
\text { Group }\end{array}$ & 34 & $\mathbf{6 2 , 3 2}$ & 7,41 & $\mathbf{7 1 , 1 4}$ & 6,71 \\
\hline
\end{tabular}

Table above describes that there are improvement on the mean score in the two groups on the post-test compared to the pretest results. But, the experimental group's score on the post-test improved much better after the treatment. The mean score improved from $61.14(\mathrm{SD}=9.06)$ in the pretest to $79.76(\mathrm{SD}=7.56)$ in the post-test of the experimental group. Whereas, the mean score improved from 62.32 in the pre-test become $71.14(\mathrm{SD}=6.71)$ in the post-test of the control group. In other words, the result showed that, the mean score of the experimental group is higher than the mean score of the control group on the post-test after the treatments. This finding confirmed that the students who used Google Classroom in learning English outside the classroom obtained higher score than the students who did not use it.

To investigate the improvement of students' English ability before and after conducting the treatments, a chart was made by the researcher. The improvement of the scores could be seen as following.

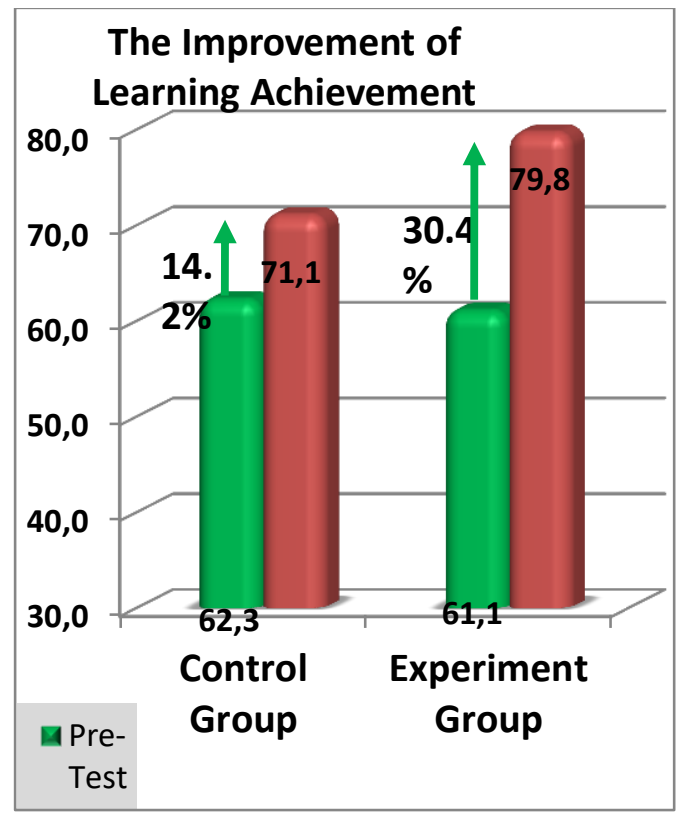

Figure 2: Learning Achivement Chart

Figure 2 indicates that there were improvement on the students' English learning achievement on both groups. However, there is greater improvement on experimental group or the students who used Google Classroom in learning English than control group who only use conventional method. There is about $30.4 \%$ improvement on students' learning achievement in the experimental group learning after using Google Classroom. Whereas, there is only about $14.2 \%$ improvement on the control group. Therefore, Google Classroom is effective in improving university students' English achievement.

Thus, the researcher realized that using Google Classroom in learning English was flexible to use since the students could access it at anytime and anywhere via smartphone. The researcher also interpreted that the novelty element of using Google Classroom which providing English materials and assignment submission via smartphone or computer was interesting for the students. Besides, the students also got 
more exposures to various materials and assignment through the use of Google Classroom in blended learning. This condition could improve the students' vobulary, gammar and reading comprehension skill. As the result, it improved the students' motivation and their autonomus learning by practicing their English skills not only in the classroom but also outside the classroom. In short, the strengths of Google Classroom enhanced students' motivation in learning English and gave contribution to the students' learning outcomes.

This finding was in line with the findings of several previous related studies. First, Albashtawi and Khaleel (2020) found that Google Classroom can greatly improve the college students' performance of English as a Foreign Language especially on their reading and writing skills. Google Classroom was used as hybrid learning to support students' learning activities. The students got more materials and assignment through Google Classroom during the treatments. Besides, the students showed positive attitudes toward using Google Classroom in terms of its usefulness, ease of use and accessibility. Their study proved the success of Google Classroom platform for learning reading and writing skills. Second, the study conducted by Oweis (2018) investigated the effect of blended learning on university students' English achievement and motivation. He found that the experimental group who conducted Google Classroom in learning English performed better scores than the control group who did not use Google Classroom in learning English. His finding also showed there were several factors that increasing students' motivation in learning English namely the teaching method, novelty element, and students' willingness. Next, this finding also coincided with DiCicco
(2016) who concludes Google Classroom had a positive impact on the middle school students' outcomes. The students were required to accomplish various assignments using Google Classroom for nine weeks before they were assessed by using vocabulary tests. His finding showed that students who used Google Classroom in learning activities increased their score in vocabulary compared to students who only used textbooks and printed materials. In addition, the students have positive responses regarding their learning by using Google Classroom.

Finally, the researcher assumes that Google Classroom could support students in learning English language and gave significant effect on university students' ability. From the result, it confirmed there were statiscally significant differences between the students' English ability of the both groups due to the use of Google Classroom in blended learning environment.

\section{CONCLUSION}

This study investigated the effect of using Google Classroom on university students' English ability. The findings indicated that using Google Classroom in learning English significantly effect the students' English achievement. Initially, there was no significant difference in the mean score between experimental group (61.14) and control group (62.32) at the 0.05 level $(\mathrm{t}=$ 0.694, P >0.05). Furthermore, after conducting treatments by using Google Classroom in blended learning English, the result of the post-test revealed that there was a statistically significant difference on both groups. It showed that the mean score of the experimental group was 79.76.14 and the mean score of the control group was 
71.14. Thus, comparing t-test 5,270 with ttable $2.042 \quad(\mathrm{df}=33, \mathrm{P}<0.05)$ we could conclude that t-test was higher than t-table. In means that there was a significant effect of using Google Classroom on students' English ability.

In conclusion, the use of Google Classroom platform in blended learning is effective in improving university students' English ability. Based on the finding of the research, the researcher recommends the teachers and lecturers to use Google Classroom to improve their students' English ability as this application can motivate and support the students in learning English at anytime and anywhere. The researcher also hopes other researchers continue conducting future studies related to the use of Google Classroom on another context.

\section{REFERENCES}

Albashtawi, A. H \& Khaleel, B. A. 2020. The effectiveness of Google Classroom among EFL students in Jordan: an innovative teaching and learning online platform. iJET Vol. 15, no. 11.

Al-maroof, R.A.S \& Al-Emran, M. 2018. Students Acceptance of Google Classroom an Exploratory Study Using PLS-SEM Approach. iJET Vol.13, No. 06.

Dewle, M. 2019. Use Google Classroom as a tool to improve listening skills in an EAP classroom. A Journal of Teaching English Language and Literature.

DiCicco, K. M. 2016. The effects of Google Classroom on teaching social studies for students with learning disabilities. Theses and Dissertation. Retrieved from https://rdw.rowan.edu/etd/1583/.

Fonseca, K. A. B \& Peralta, F. S. Google Classroom: an effective virtual platform to teach writing in an EFL composition course. Internatioanal Journal of English Language Teaching. Vol. 6, No.1.

Gay, L. R, Geoffrey, E. M, \& Airasian, P. 2009. Educational Research:

Competencies for Analysis and Applications. 9th Ed. Pearson Education: New Jersey.

Haggag, M. H. 2019. Using Google Classroom in Enhancing Communicative Grammar Use and Attitudes of Non-English Specialized Post Graduates. Europian Scientific Journal. Vol. 15. No. 1.

Hinneburg, J. J., Luhnen. A, Steckelberg, and B. Berger-Hoger. 2020. A blended learning training programme for health information providers to enhance implementation of the Guideline Evidence-based Health Information: development and qualitative pilot study. BMC Med Educ 20 91):77.

Iftakhar, S. 2016. Google Classroom: What Works and How? Journal of Education and Social Sciences. Vol. 3, pp.12-18.

Janzen, M 2014 Hot Team: Google Classroom. Retrieved from http://tlt.psu.edu/2014/12/04/hotteamGoogleclassroom

Junaidi, A et al. 2020. Panduan Penyusunan Kurikulum Pendidikan Tinggi di Era Industri 4.0 untuk Mendukung Merdeka Belajar - Kampus Merdeka. Direktoral Jenderal Pendidikan Tinggi, Kementerian Pendidikan dan Kebudayaan. Edisi IV. Jakarta.

Kintu, M., Chang, Z., \& Edmond, K. 2017. Blended Learning Effectiveness: The relationship between students characteristics, design features and outcomes. International Journal of Educational Technology in Higher Education. Springer. 
Kuh, G. D., \& Hu, S. (2001). The relationships between computer and information technology use, selected learning and personal development outcomes, and other college experiences. Journal of College Student Development, vol. 42, pp. 217-232.

Nagelle. 2017. Google Classroom. Udemy. Retrieved from: https://www.udemy.com/googleclassro om/

Negara, I. M. 2018. Students Perception: The use of google classroom in teaching-learning process. Jurnal Ilmiah STBA, Vol.4 No. 1.

Oweis, T.I. 2018. Effects of Using a Blended Learning Method on Students' Achievement and Motivation to Learn English in Jordan: A Pilot Case Study. Hindawi. Education Research International. Vol. 2018.

Siddiek, A.G., 2010. The Impact of Test content validity on language Teaching and Learning, Shaqra University, Asian social science journal, 6(12): 133-140.

Siddiek, A.G., 2010. Standardization of the Saudi Secondary School Certificate Examinations and their Anticipated Impact on Foreign Language Education, International journal of humanities and social science, VOL. 1 NO. 3.

Syakur, Abd., Sugirin, \& Widiarni. 2020. The effectiveness of English learning media through Google Classroom in higher education. Britain International of Linguistic, Arts, and Education Journal. Vol. 2, No.1.

Underhill, N., 1991.Testing Spoken Language. Cambridge: Cambridge University Press.
Wahyu, d. S, Bambang, Y. C, \& Utari. P. A. 2018. Effect of blended learning using Google Classroom on writing ability of EFL students across autonomy levels. Teaching English with Technology Journal. 20(2), 82-87. 